\title{
PARTNERSHIP AND GOVERNANCE FOR SMART CITIES
}

\author{
Catalin Vrabie ${ }^{1}$
}

DOI: 10.24989/ocg.v.338.3

\begin{abstract}
Many smart city publications talk of a need for new models of partnership working: public-private partnerships that create a shared vision for the smart city, bringing together leaders from city government, national government, health services, universities, business, social enterprises and the community sector. But as it is already known, crucial to the acceptance and success of smart cities is the involvement of citizens. Cities in which citizens take a central role are creating public-privatepeople partnerships.
\end{abstract}

There's no clear beginning or end to the process of becoming smart: the road to smart cities is a transition process that can take 10, 15 or even 20 years. Today's decisions on city infrastructures and services will have consequences for the future generations who live in the city. There needs to be a huge cultural shift away from working in silos and towards integration across organizations, cities and countries. Smart city partnerships need to bring people together but they also need to be a vehicle that commissions and manages smart infrastructure and technology, dealing with issues such as finance, privacy and security.

This paper will discuss about this issue providing examples of success stories found in Europe and across the world.

\section{Introduction and context}

At a European level the European Commission has established the European Innovation Partnership on Smart Cities and Communities (EIP-SCC), which brings together cities, industries, SMEs, investors, researchers and other smart city actors to improve urban life through more sustainable, integrated solutions [10], [13]. The platform is able to help partnerships initiatives to:

- $\quad$ Find the latest news, events and documents related to innovation in Smart Cities;

- $\quad$ Find information on many existing EU funding sources;

- $\quad$ Launch debates on a specific issue, initiative or practice;

- $\quad$ Share information, documents and links to enhance the visibility of specific events;

- $\quad$ Find interesting completed or ongoing smart cities projects;

- $\quad$ Get in touch with potential partners or peers who work on the same subject.

By putting resources together, a partnership is looking to cofound projects, to help organise existing initiatives at the metropolitan level in order to overcome the bottlenecks that might slowdown or disrupt a specific process.

\footnotetext{
${ }^{1}$ National University of Political Studies and Public Administration (SNSPA), Expozitiei blvd. no. 30A, Bucharest, Romania, E-mail: vrabie.catalin@gmail.com
} 
However, cities are embracing different formulas of smart city partnership. Some are choosing for an informal partnership where actors sit together and share experiences, work on ideas development and look for financial backing; this is mostly common for cities that started developing a smart city initiative with a bit of a delay comparing with those in the pole position. Some others consider adopting a more formal model. Cities like Amsterdam, Lyon, Genoa, Copenhagen, Hamburg and Vienna showed their intention by signing a Memorandum of Understanding that is conducted by the city administration and is mutually signed by companies that enrol in the city life. The cities learn from each other, also projects can be scaled up to other cities [24].

As smart city programs are becoming larger and their numbers are increasing, city administrations need to consider more formal model structures for their smart city partnerships, models that reflect the requirements, as well as aims, of all the actors. A good administration structure needs to be built on the objectives of a partnership and to allow it to be managed in a transparent and accountable way [23]. It is also necessarily to tackle issues like who are the decision makers, how they are accountable and to whom [22]. It will also be important to acknowledge where the finance has come from and who controls it, as well as any other form of capital or intellectual property [8]. The legal framework is also important - here it must be taking into consideration the differences that exist in the legal systems around the world and to be understood that it is impossible for one model to fit all needs [12]. Nevertheless, an important aspect to look at is the link with the latest technology; Industry 4.0 involves huge productivity gains in the manufacturing industry and there is no doubt that similar benefits may be reaped by public administration, particularly on the municipal level [21].

\section{Partnerships and their place on a smart city strategy}

A strategy sets the main direction to be followed by a smart city initiative; a course of action that heads towards the aims and objectives [16]. It might also contain a roadmap in which actions are positioned along a timeline [20].

Some cities start creating a smart city strategy and/or roadmap when they initiate their smart city work, (e.g. Bucharest) [5]. Others are focusing first on building innovative projects and after they get enough experience with it, they start develop a strategy or roadmap (e.g. Dubai) [25].

The Smart City concept is not new. It gained most of its volume in today's researches due to the wider sustainability and technology initiatives and to the approaches that involves inserting smart city actions into existing city development strategies. The term 'digital plan' or 'digitalization plan', as is most commonly used in Romania, is sometimes used in place of 'strategy' or 'roadmap'. Often, smart city tactical actions might be integrated into a wider city development plan.

In the specific case of a city, the main value of a strategy is in bringing together all the actors to create a common vision. They will commonly consider where a city is today and its aims for the future, and by that, they will build up plans to get there finding the proper investments areas and prioritize them [15]. It is also important to take into consideration that as soon as a strategy is written it will go outdated because cities and technology are changing at a very fast rate. But if it is flexible it can provide a useful framework for measuring and reviewing a city's progression towards becoming smart(er) [15]. Having a strategy in place, along with a good leadership, can also maximize its potential and help design different kinds of funding and form of investment. 
How does a city determine where to start? The administration must carefully consider what it wants to achieve by looking at the challenges and opportunities of the city and its citizens, and what the city's strengths are. All of these should be used to create the smart city vision and guiding principles.

It's also important for all the actors engaged in to process to see and understand what a city has already: for example, existing partnerships and programs on which a smart city initiative would be build. A smart city partnership might obtain this by engaging a broad range of actors and stakeholders. Political leadership is important, but equally important is the involvement of citizens and business in shaping the future direction of their city [14].

It might be also important to have a timetable for city initiatives in order to ensure these are properly done and a timescale to measure them. What is it known in the literature as key performance indicators (KPIs) allow progress and success of the city strategy by being easily tracked, review and reported [28].

One of the biggest challenges in creating a strategy or roadmap is not to focus on setting up clear actions early on [27] due to the high risk of limiting creativity, innovation and enterprise. Cites demands and the technologies made to fulfill them are constantly evolving. Expert smart city strategist Ger Baron, who was deeply involved in establishing Amsterdam Smart City (being now Amsterdam's chief technology officer), made the observation that 'the concept of smart cities is like art: the context is more important than the product' [11]. He has some concerns about the idea of building up a roadmap and believes that while an instrument to measure progress is needed, this should not be the same type of a roadmap used by private sector who is focused on financial gains and not on public interest. Amsterdam has focused on creating a platform on which all actors involved can work together on innovative projects, bringing together innovators and investors.

\subsection{Amsterdam Smart City}

The city of Amsterdam - the capital city of The Nederland, built up a dedicated platform for innovation aiming to bring together proactive citizens, innovative companies, knowledge institutions and public authorities to shape the city of the future.

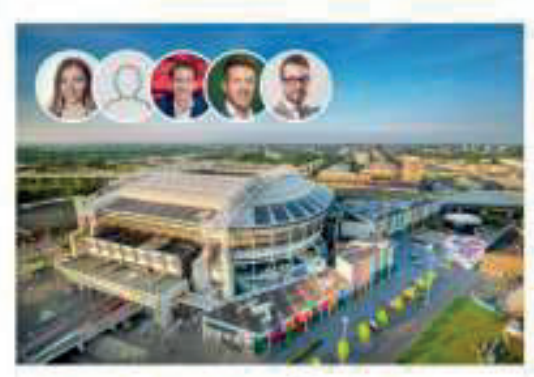

Amsterdam Innovation Arena World's lesding smart playground

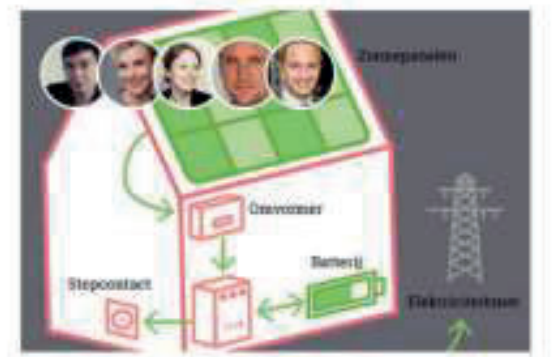

City-zen: Virtual Power Plant

"Project endeo" Storage and trade of surplus solar energy through home batterises

842

amaer anies is.

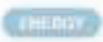

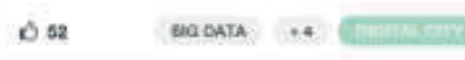

Figure 1: Amsterdam Smart City Web platform [2]

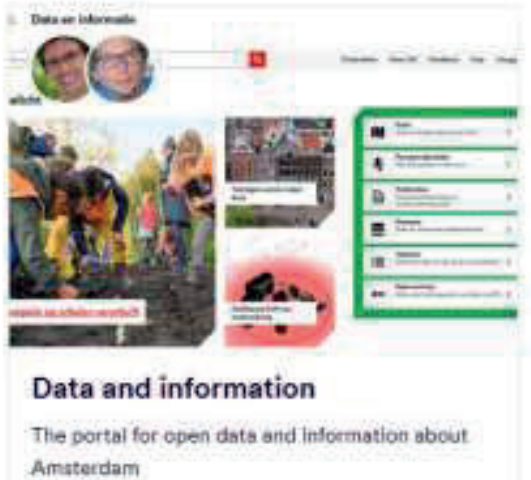

Amsterdam

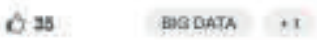


The idea behind consists on establishing public-private partnerships among national and international actors [2]. By the end of 2019, the platform managed to bring at the same table more than 7000 innovators (users as individuals and companies or institutions) connecting everyone with energy and ambitions to improve the livability in urban areas. The platforms help communities to connect and share expertise and strengthens new projects that make the region futureproof.

By the moment of the research conducted for the present article, the platform successfully published a number of 299 projects divided into six categories such as: Digital city, Energy, Mobility, Circular City, Governance \& Education and Cities \& Living. The most voted projects are getting attention and by that partners might get involved either financially or by other means (i.e. human resources, voluntaries, expertise in different areas etc.).

\subsection{Birmingham Smart City}

Birmingham City Council published in 2010 its Core Strategy 2026 integrating the Smart City Vision statement. Soon after that the Birmingham Smart City Roadmap has been developed - for doing this a group of city stakeholders were involved. The roadmap describes an initial range of activities and sets up actions that are designed to influence the city's approach in creating a sustainable living environment. It identifies threats like unemployment, skills gap and/or digital divide, different form of inequalities, and sets up targets like effective mobility and carbon reduction. All those are grouped into three main areas: technology and place, people and economy. The actions are being tackled in collaboration with both private and public sector.

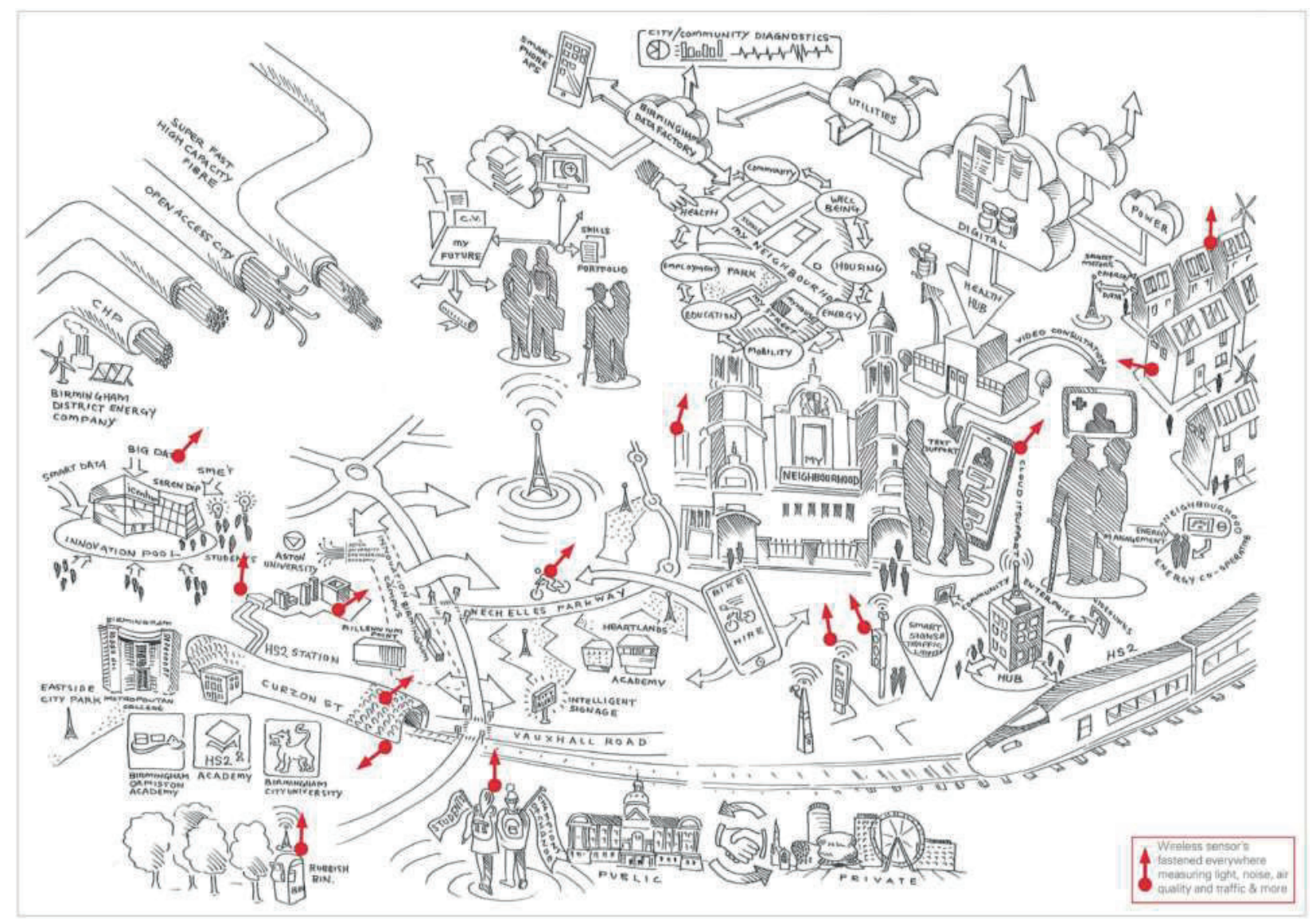

Figure 2: Birmingham Fast Forward 2026 [6] 
As an important tool, there is also a Birmingham Smart City blog, which is run by the community as a place to share ideas and developments for making Birmingham a smarter city [6].

\subsection{Chicago Smart City}

As far as 2013, the city of Chicago in United States of America published 'The Chicago Technology Plan', highlighting 28 initiatives on five broad areas that are set up to fuel opportunity, inclusion, engagement and innovation in order to empower Chicago to realize its vision of becoming the city where 'technology is driven by the people who use and benefit from it' [7]. The plan's stated main purpose is to enable Chicago's residents and businesses to be digitally-connected and by that the technology to contribute to enriching the quality of life, employment opportunities and business growth in the city. The officials are actively engaged in the following trendlines:

- $\quad$ Cutting costs/improving taxpayer and government finances;

- Improving the type of services/information provided by the City;

- Bringing Chicago's citizens together to solve issues through innovation;

- $\quad$ Providing access to the Internet, computers, software, and support;

- Developing computer skills and a level of comfort in becoming digitally active;

- Creating new jobs;

- Attracting/retaining Science, Technology, Engineering, Math professionals.

However, a city doesn't become smart based on just the reach of its broadband network or the detail of its data sets, but by empowering citizens to work together, to pursue opportunities, and to make the city a better place to live and work - that's what makes a city smart. Five years later than 'The Chicago Technology Plan` was publicly released, Chicago reached the top three on the 'most sociable and friendly cities in the world ranking according to Business Insider [3].

\subsection{Dubai Smart City}

The Dubai Plan 2021 describes the future of Dubai through holistic and complementary perspectives, starting with the people and the society. It has six main areas of development, each of them highlighting a group of strategic aims for the city. For example, one theme, 'The experience: the preferred place to live, work \& visit', focuses on high-quality experiences that Dubai provides to its residents and visitors as being one of the most critical advantages the city has to offer. This theme focuses on improving Dubai's livability by building on and improving this experience. It addresses the need to provide the best educational, health, and housing services to all residents, while availing a rich cultural experience and entertainment options such as parks, beaches, and sports facilities that cater to local residents and attracts tourists, in the safest and most secure environment possible [25].

Now, at the beginning of 2020 and by that mostly on the edge of the Dubai Plan 2021, researches made on the city are not arguing about its success. According to Mastercard [17], Dubai is one of the world's most visited cities with about 16 million tourists yearly. According to the same article, each visitor is spending about four nights in the city and around 550 USD per day. To compare, Paris - as being a well-known routinely tourist destination for decades, with no further citing needed, however, according to the same source, attracts around 20 million tourists that are spending on average three nights inside the city and a total amount of money equal to 300 USD per day. 


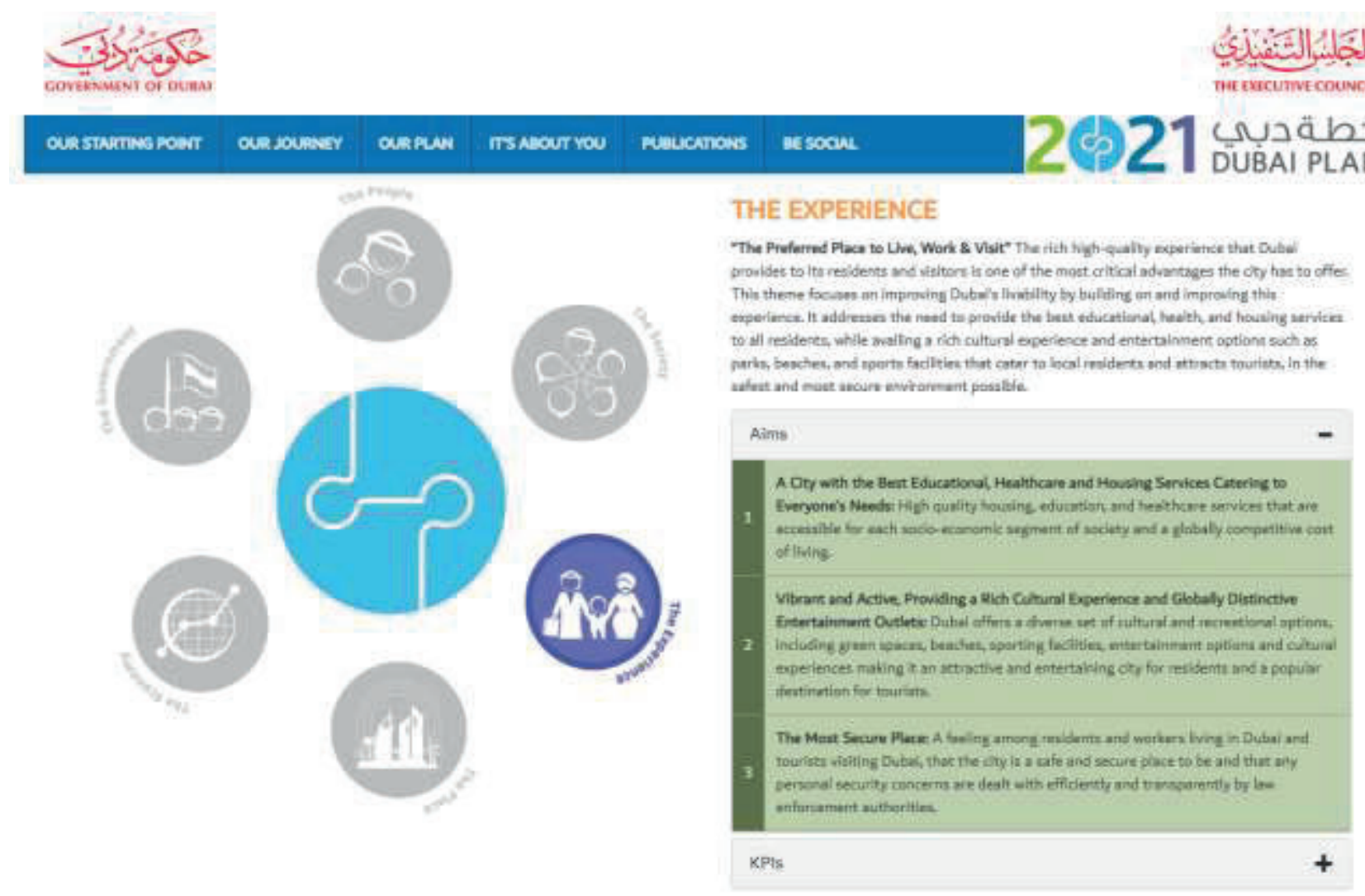

Figure 3: 2021 Dubai Plan [25]

\subsection{Iasi Smart City}

A Romanian example worth mentioning is that of the city of Iași, which was selected by the European Commission at the beginning of 2018, through The Digital Cities Challenge program, to be given high level advice and support by both local and international experts in order to help develop and implement strategic plans for economic growth and social welfare [9]. The dialogue with other city officials in Europe that have been involved in the transition process to become smart, together with the access to a whole network of European partners who can provide assistance and advice, helped developing a strategy and, based on it, an action plan to digital transform the city. Those are just a few of the benefits of such partnership programs.

If ten years ago the city of Iași was not to be found on any rankings on smart cities, at the end of 2019 the city proudly participated at the Digital Cities Challenge, wining the Best Smart City Project of the Year 2019 at Smart City Industry Awards [4]. Also, Iași holds the presidency of the Open \& Agile Smart Cities Romania - all those because of the partnerships that he managed to be part of.

\section{Smart leadership}

According to the literature, the biggest barrier in implementing IT solutions at the municipal level is management failure [29], [19], [26]. A British initiative called CITIE (City Initiatives for Technology, Innovation and Entrepreneurship) raised up as a product of a partnership between Nesta - an innovation charity with a mission to help people and organisations bring great ideas to life, Accenture - a leading global professional services company, providing a broad range of services and solutions in strategy, consulting, digital, technology and operations, and the Future Cities Catapult - a consortium between universities and city leaders in UK, in order to support city managers to 'develop 
policy to catalyse innovation and entrepreneurship' [1]. It is, in fact, an idea to smart up the city managers.

On the CITIE's website there are a lot of ideas of partnership's use - some as described above. The aim of CITIE is to bring these together and analyse them in a systematic way. By that, the team observed an increased focus of policy instruments that were emerging from a growing number of cities to support their innovation and entrepreneurship ecosystems.

CITIE focuses exclusively on the policy levers that city government leaders have at their disposal, equipping city leaders with a guide to support innovation and entrepreneurship. Policy levers are measures that change the behaviour of individuals or groups [18].

The principal components of CITIE are as follows:

1. a framework for assessing how well policy supports innovation and entrepreneurship;

2. a diagnostic tool to help cities assess how they compare to their peers;

3. a package of case studies containing global best practice across the nine policy areas.

The framework identifies three key areas in which a city can support innovation and entrepreneurship.

1. Openness: how open is the city to new ideas and businesses?

2. Infrastructure: how does the city optimise its infrastructure for high-growth businesses?

3. Leadership: how does the city build innovation into its own activities?

Within each of these areas it identifies roles a city can play, with city case studies.

For example, focusing on the topic of 'Openness' a city can promote itself and its small business community to the outer world. Smart city start-ups need to invest a great deal of time, energy and resources in building their reputation and networks. This is an area where city leaders have precisely the kind of reach and convening power that small businesses need, so by working in partnerships they can support innovation and entrepreneurship. Berlin provides extensive support for start-up companies to test out the city, allowing them to get established, operate and expand in the city at minimal cost [18].

In 'Leadership' a city can be a strategist. This is where the city sets a clear direction and builds the internal capabilities required to support innovation. The Smart London Plan, for example, was published by the Smart London Board to set out the role of digital technology in helping to address key city challenges such as rapid population growth and to improve Londoners' lives [18].

\section{Romanian insights}

During the last three years, Romanian cities are building their own strategies for smart development. Bucharest, despite the fact that it is the capital city, is not leading the initiatives; however, is trying to reach up by paying a close attention to working motels across the world in order to adapt them on its benefit. The author of this paper is often a member of the working groups that meant to build up 'strategies on digitalization` or 'development' as they are to be found in the city halls agenda. 
The members of such working group need to interview the city officials - in order to understand the framework and the resources needed for development, as well as the civil society to collect its views (or sometimes ideas) on the proposed mainlines.

A dedicated chapter on the partnership and leadership is to be found on the final document which is usually entitled: 'The strategy for sustainable development'.

All of the ideas and examples above were presented to officials of Bucharest districts - the Romanian capital is divided in six districts, asking them to deliver their views on the past, or existing, partnerships. During the interviews we extract the following as being the main operational issues to be considered in a partnership agreement between a town hall and some other entities (such as: private companies, other public institution, academia, civil society):

1. Degree of commitment;

Most of the municipality's officials consider important how much work each partner is to do in a specific project. Often, public institutions (i.e. town hall) get involved only financially and in situations like this one they do not want to be required to take part in the daily running of the project. Also, they might want to get involved partially or only to supervise the implementation. An agreement should set out the degree of commitment of each partner. For a full-time working partner - usually a private company but sometimes a university or a consortium, this may be expressed as devoting its whole time and attention to the project.

2. Leadership Hierarchy;

All officials agreed that it is mandatory to maintain a clear-cut leadership hierarchy in order to be effective and efficient. However, this does not mean that the rest of the partners do not have a say in the project, but there is a strong need that one clearly defined leader exists. Same goes for the financial hierarchy and who will be responsible for fiscal requirements the project must meet.

3. Decision-making;

Unless otherwise agreed, all partnership decisions should be made on a majority basis by one partner one vote. However, if it is a decision on changing the nature of the project or the involvement of a new partner, then every partner must agree. Therefore, it might well be that this is not what partners in a particular project want. For example, it may be a good idea to state that certain decisions can be made by one partner alone - the project coordinator (usually the town hall), while some other decisions might require a majority vote, or the consent of all the partners. In any case all those scenarios should be clearly stated from the very beginning.

4. Liability;

partners are jointly responsible for all the commitments, debts and obligations of the project, including loss and/or extra charges, damages arising from wrongful acts or omissions of their fellow partners and potential liability to third parties.

5. Flexibility;

the partnership structure should be flexible, with full freedom to agree on how the project should be managed and financed.

\section{Summary and conclusions}

The style of a smart city project development and/or implementation depends on the priorities and aspirations of whoever leads the work, as shown in the case studies presented in the present article. 
Currently it is still common for city government to manage smart city programmes and tender projects when they need other parties to deliver aspects of the programme. In this case a memorandum of understanding should be used. However, in the future, some other approaches might appear.

Usually, the municipalities officials are convinced that the changes necessary for the city to move forward can only be achieved through collaboration. Pooling brainpower, skills and networks will facilitate creating better streets, neighbourhoods and cities, and address the most important transitions we're facing today.

If we are to take, as a final example, the city of Amsterdam, its partners are governments, knowledge institutions, companies and foundations. In the smart city program they build up they are focusing on four societal transitions: Energy, Digital City, Circular City and Mobility. The idea was copied by the second large city in Romania - Cluj-Napoca, who managed to acquire a well-deserved place in the smart cities ranks in Romania being, arguably, the smartest city in the country - and this was done by multiple partnership agreements.

\section{Acknowledgements}

This paper was possible with the financial support of the National University of Political Studies and Public Administration, Bucharest, Romania, under the project 'Minigranturi SNSPA 2019' with the title "From smart cities to smart nation. Synergy of smart projects implemented at city level in Romania ".

\section{References}

[1] ACCENTURE, City initiatives for technology, innovation and entrepreneurship. The northern Powerhouse Analysis https://www.accenture.com/_acnmedia/pdf-24/accenture-citie-northernpowerhouse-final-report-new.pdfla=en-gb (Accessed: January 2020)

[2] AMSTERDAM SMART CITY, Let's create better cities, neighbourhoods and streets!, https://amsterdamsmartcity.com/network/amsterdam-smart-city, (Accessed: December 2019)

[3] BUSINESS INSIDER, The 19 most sociable and friendly cities in the world, https://www.businessinsider.com/the-most-sociable-friendly-and-liberal-cities-in-the-world2017-2? $\mathrm{r}=\mathrm{US} \& \mathrm{IR}=\mathrm{T}$ (Accessed: December 2019)

[4] BUSINESS REVIEW, Iasi City Hall joins the Romanian Smart City Association, https://business-review.eu/news/iasi-city-hall-joins-the-romanian-smart-city-association207652 (Accessed: January 2020)

[5] CAPITAL, Romanian capital city is reaching the technological era and heads to Smart City! (in Romanian) https://www.capital.ro/anunt-pmb-capitala-ajunge-in-era-tehnologiei-si-devinesmartcity-inovatii-importante-pentru-bucuresteni.html (Accessed: December 2019)

[6] CITY OF BIRMINGHAM, Birmingham Core Strategy 2026. A plan for sustainable growth, 2010, www.birmingham.gov.uk/download/downloads, (Accessed: December 2019) 
[7] CITY OF CHICAGO, The Chicago Technology Plan, 2013, https://techplan.cityofchicago.org/wp-content/uploads/2013/09/cityofchicago-techplan.pdf, (Accessed: December 2019)

[8] DAMERI, R. P., Comparing Smart and Digital City: Initiatives and Strategies in Amsterdam and Genoa. Are they digital and/or smart? in: Smart City: How to Create Public and Economic Value with High Technology in Urban Space, Springer 2014.

[9] DIGITAL CITIES CHALLENGE, Iași digital transformation strategy, https://www.digitallytransformyourregion.eu/cities/iasi (Accessed: December 2019)

[10] EIP-SCC, The European Innovation Partnership on Smart Cities and Communities, https://eusmartcities.eu/ (Accessed: December 2019)

[11] EUROFORUM NEDERLAND, Interview with Ger Baron - Smart Cities, Euroforum Nederland official YouTube channel, 2014

[12] EUROPEAN COMMISSION, Laws about Smart cities in: Digital Single Market, https://ec.europa.eu/digital-single-market/en/laws/76019/73883. (Accessed: December 2019)

[13] EUROPEAN COMMISSION, Smart cities in: City initiatives, https://ec.europa.eu/info/euregional-and-urban-development/topics/cities-and-urban-development/city-initiatives/smartcities_en. (Accessed: December 2019)

[14] FUTURE LEARN, Ethical Cities: Shaping the Future of Your City, https://www.futurelearn.com/courses/ethical-cities, (Accessed: December 2019)

[15] IOT WORLD TODAY, 7 smart city strategies from cities across the world, https://www.iotworldtoday.com/2017/10/05/7-smart-city-strategies-cities-across-world/ (Accessed: December 2019)

[16] KASPAROV, G., How Life Imitates Chess, Arrow Books, London, 2008

[17] MASTERCARD, Mastercard Global Destination Cities Index 2019, https://newsroom.mastercard.com/mea/press-releases/dubai-remains-one-of-the-worlds-mostvisited-cities-mastercard-global-destination-cities-index-2019/ (Accessed: December 2019)

[18] NESTA web site, https://media.nesta.org.uk/ (Accessed: December 2019)

[19] OECD - Organisation for Economic Co-operation and Development web site [online] http://www.oecd.org/dataoecd/60/60/2502539.pdf (Accessed: December 2019)

[20] PHAM, T., PHAM D., K. and PHAM A., G., From Business Strategy to Information Technology Roadmap, Taylor \& Francis Group, 2013

[21] PROSSER, A., What the Smart City in the Danube Region Can Learn From Industry 4.0, in: Proceedings of the Central and Eastern European E|Dem and E|Gov Days, Budapest, 2018. 
[22] RODRÍGUEZ-BOLÍVAR, M. P., Transforming City Governments for Successful Smart Cities. Springer, Switzerland, 2015.

[23] RUČINSKÁ, S. and FEČKO, M., Electronic services or smart cities - Current experiences and perspectives in the Slovak Republic, in: Proceedings of the Central and Eastern European E|Dem and E|Gov Days, Budapest, 2019

[24] SMART CIRCLE, Implementing the Smart City approach, https://www.smartcircle.org/smartcity/blog/implementing-smart-city-approach/, (Accessed: December 2019)

[25] SMART DUBAI, Our vision is to make Dubai the happiest city on earth, https://www. smartdubai.ae/ (Accessed: December 2019)

[26] UN E-Government Survey 2014. https://publicadministration.un.org/egovkb/en-us/Reports/ UN-E-Government-Survey-2014 (Accessed: December 2019)

[27] VAN BEURDEN, H., Smart City Dynamics, Inspiring views from experts across Europe, HvB Communicative BV, 2011

[28] VRABIE, C. and DUMITRAȘCU, E., Smart Cities, from idea to implementation; or how technology can make the urban environment shine, Universul Academic, Bucharest, 2018

[29] VRABIE, C., E-Governments fundamentals, Ed. ProUniversitaria, Bucharest, 2016. 